Article

\title{
Programmed Death Ligand 1: A Poor Prognostic Marker in Endometrial Carcinoma
}

\author{
Mianxin Chew ${ }^{1,2}$, Yin Ping Wong ${ }^{1}$, Norain Karim ${ }^{2}$, Muaatamarulain Mustangin ${ }^{1}$, \\ Nurwardah Alfian ${ }^{1}$ and Geok Chin Tan ${ }^{1, *(D)}$ \\ 1 Department of Pathology, Faculty of Medicine, Universiti Kebangsaan Malaysia, Jalan Yaacob Latif, \\ Bandar Tun Razak, Kuala Lumpur 56000, Malaysia; mianxinchew@gmail.com (M.C.); \\ ypwong@ppukm.ukm.edu.my (Y.P.W.); amar@ppukm.ukm.edu.my (M.M.); \\ nurwardah@ppukm.ukm.edu.my (N.A.) \\ 2 Department of Pathology, Hospital Raja Permaisuri Bainun, Jalan Raja Ashman Shah, Ipoh 30450, \\ Perak Darul Ridzuan, Malaysia; norain33@gmail.com \\ * Correspondence: tangc@ppukm.ukm.edu.my; Tel.: +60-391455362
}

Received: 19 April 2020; Accepted: 9 June 2020; Published: 11 June 2020

\begin{abstract}
Endometrial carcinoma is the only gynaecologic malignancy with a raising incidence and mortality, posing a major health concern worldwide. The upregulation of programmed death ligand 1 (PD-L1) on tumour cells causes T-cell suppression, which impedes antitumour immunity, promotes immune cell evasion and enhances tumour survival. The aim of this study was to evaluate PD-L1 expression in endometrial carcinoma and to correlate it with survival rate. A total of 59 cases of endometrial carcinoma were evaluated. Thirty-two cases of non-neoplastic endometrial tissue were included as control. PD-L1 immunohistochemistry was performed on all cases. PD-L1 expression was evaluated on tumour cells and immune cells. PD-L1 was positive in $62.7 \%(37 / 59)$ and $28.8 \%(17 / 59)$ of immune cells and tumour cells, respectively. PD-L1 expression in immune cells was significantly higher in endometrial carcinoma than in non-neoplastic endometrium $(p<0.001)$. Among the patients with endometrial carcinoma, PD-L1 expression in tumour cells was significantly higher in patients who died $(10 / 15,66.7 \%)$ compared to those who survived $(7 / 44,15.9 \%)(p<0.001)$. It is noteworthy to point out that the expression of PD-L1 in tumour cells was significantly associated with a poor survival. This suggests that immunomodulation using PD-L1 inhibitors may be useful in advanced endometrial carcinoma.
\end{abstract}

Keywords: endometrial carcinoma; PD-L1; prognostic factor; gynaecology; pathology

\section{Introduction}

Endometrial carcinoma is a heterogeneous group of tumours derived from endometrial glandular epithelium. It is the most common gynaecological cancer in USA, and was estimated to have 61,880 new cases and 12,160 mortalities in 2019 [1]. In Malaysia, endometrial carcinoma is the third most common gynaecologic cancer and is the seventh most common cancer among woman [2]. It is the only gynaecologic malignancy with a rising incidence and mortality $[3,4]$ and pose a major health concern worldwide.

Endometrial carcinomas are divided into type I and type II that possess different aetiologies, clinical behaviour and outcome $[5,6]$. Type I endometrial carcinoma includes endometrioid adenocarcinoma and mucinous carcinoma that are associated with unopposed oestrogen exposure, and this group accounts for $70-80 \%$ of endometrial carcinoma. Type II endometrial carcinoma consists of papillary serous carcinoma, clear cell carcinoma, undifferentiated carcinoma and carcinosarcoma. The latter group is associated with p53 mutation and has a lesser degree of association with unopposed oestrogen exposure [7]. 
Most of the patients with endometrial carcinoma are diagnosed and treated at an early stage of disease with favourable outcomes. However, some patients are diagnosed at more advance stage and suffer poor outcome with limited treatment options and a low survival rate [8].

Endometrial carcinoma is routinely managed with surgical resection with or without pelvic radiotherapy and has a 5 -year survival rate of $95 \%$ if the disease is confined to the uterus. However, if the disease has metastasised, the 5-year survival rate reduces greatly to $17 \%$ [3]. They usually have a limited response rate to cytotoxic chemotherapy, targeted agents and hormonal therapy. The triplet regime (paclitaxel, doxoruicin, ciplastin) used in endometrial carcinoma had a disappointing overall response rate of $57 \%$ and overall survival rate of 15.3 months [9]. On the other hand, targeted agents such as beracizumab/temsirolimus gave a response rate of $<24.5 \%$, while hormonal therapy such as taxane showed a response rate between 18 to $34 \%$ [10].

Recently, researchers started to explore a new therapeutic approach which is gaining popularity, namely, immunotherapy with a focus on the tumour microenvironment. One of the potential immunotherapies is the immune checkpoint inhibitor. The immune checkpoint is an inhibitory pathway in the immune system that maintains self-tolerance and minimizes damage during physiological responses to pathogens. Cytotoxic T-lymphocytes-associated protein 4 (CTLA-4) and programmed cell death protein (PD-1) are the most clinically relevant immune checkpoint receptors that are currently being investigated [11].

Programmed death ligand 1 (PD-L1) is a transmembrane protein that modulates T-cell response in normal conditions and is expressed in haematopoietic and inflammatory cells. PD- 1 is an inhibitory receptor expressed on T-cells following T-cell activation. In chronic infection and cancer, it is sustained in states of chronic stimulation [12]. The interaction between PD-L1 and PD-1 inhibits T-cell proliferation, cytokine production, and cytolytic activity. This leads to the functional inactivation or exhaustion of T-cells and results in downregulation of T-cell response. In cancer, there is upregulation of PD-L1 expression on tumour cells, which causes T-cell suppression, and this impedes antitumour immunity, promotes immune tumour cell evasion, and enhances tumour survival [13].

PD-L1 overexpression is observed in immune cells of malignant neoplasm, such as melanoma [14], renal cell carcinoma [15] and nonsmall cell lung carcinoma [16], which lead to downregulation of host response against the tumour. Recent immunohistochemical studies also show PD-1 and PD-L1 expression in endometrial carcinoma, ovarian and cervical carcinoma [17,18]. Vanderstraeten et al. discovered that PD-L1 expressions in primary, recurrent and metastatic endometrial carcinoma were $83 \%, 67 \%$ and $100 \%$, respectively [19], while Herzog et al. reported that PD-1 expression was $75 \%$ and PD-L1 expression was 25\% in endometrial carcinoma [17].

To date, anti-PD-L1 therapies are used in several types of carcinoma, namely, metastatic melanoma, nonsmall lung carcinoma (NSCLC) and renal cell carcinoma (RCC). Meta-analysis by Gandini et al. showed that anti-PD-1/PD-L1 therapy has good clinical response in melanoma and nonsquamous NSCLC, while in squamous NSCLC and RCC, they did not show a significant difference in clinical response based on the PD-L1 status [20]. Interruption of the PDL1/PD-1 interaction represents a potential strategy to prevent tumour-specific T-cell response suppression in the tumour microenvironment. However, there is limited data on PD-L1 expression in endometrial cancer. The aim of this study was to determine the expression of PD-L1 in endometrial cancer and to evaluate the utility of PD-L1 as a prognostic biomarker for endometrial cancer.

\section{Materials and Methods}

\subsection{Study Design}

This was a cross-sectional, descriptive study using archival histopathological materials from the Department of Pathology over a period of 5 years. All hysterectomy specimens diagnosed as endometrial carcinoma were included in this study. Cases with insufficient clinical data or unavailability of paraffin-embedded tissue blocks, cases with equivocal features or indefinite diagnosis, patients 
who had received neoadjuvant chemotherapy prior to tissue sampling, and cases with synchronous malignancy of the ovary were excluded from the study. Normal endometrium was obtained from hysterectomy for leiomyoma.

Clinical data including age of diagnosis, ethnicity, histological diagnosis, tumour grading, tumour staging, treatment and survival status were obtained from the medical record office and integrated laboratory system. This study was approved by the institution research ethics committee (FF-2018-052; 21 February 2018) and the national medical research and ethics committee (NMRR-17-2909-38987; 26 November 2017).

\subsection{Histological Examination}

All cases were stained with haematoxylin and eosin (HE) and reviewed. For each case, one slide with best representative of the lesion was chosen. The corresponding block was then retrieved for PD-L1 staining. An Olympus microscope BX-41 (Life Science Solution, Selangor, Malaysia) was used to determine the immunohistochemical staining in this study.

\subsection{Immunohistochemistry (IHC) Staining Method}

Rabbit monoclonal (28-8) to PD-L1 (Cat. No. ab205921, abcam, Cambridge, UK) was used at a dilution of 1:500. Normal tonsil tissue was used as positive control tissue (Figure 1). Immunohistochemical staining was performed on tissue sections following manufacturer protocol using EnVisionTM FLEX Mini Kit, High pH (Code No. K8023, Dako, Denmark). Primary antibody was diluted to optimal concentration by antibody diluent, Dako REALTM (Code No. S2022, Dako, Denmark). Washing steps between each reagent were performed using EnVisionTM FLEX Wash Buffer $20 \times$ (Code No. K8007, Dako, Denmark) diluted to a $1 \times$ working solution with deionized water. The $1 \times 3,3^{\prime}$-Diaminobenzidine (DAB)-containing substrate working solution was prepared by diluting the $50 \times$ concentrated EnVisionTM FLEX DAB + Chromogen with EnvisionTM FLEX TM Substrate Buffer (Code No. K8023, Dako, Denmark).

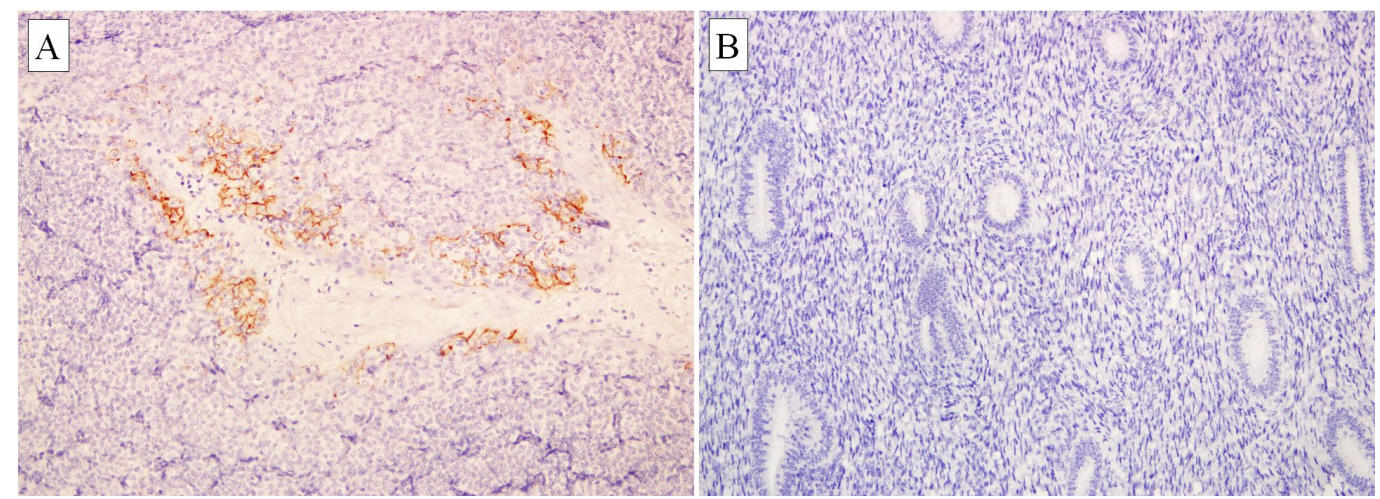

Figure 1. PD-L1 immunohistochemistry showed membranous staining. (A) Strong PD-L1 staining in immune cells of tonsils (control; 200x); (B) Negative PD-L1 staining in normal endometrium (200×).

Tissue blocks were sectioned approximately $3 \mu \mathrm{m}$ in thickness and mounted on adhesive glass slide, Platinum Pro White (Product No.: PRO-01, Matsunami, Japan). The slides were left to be air-dried in room temperature overnight. The tissue slides were then incubated on hot plate at $60^{\circ} \mathrm{C}$ for $1 \mathrm{~h}$. An initial deparaffinization and pretreatment step was performed in the Decloaking Chamber ${ }^{\mathrm{TM}} \mathrm{NxGen}$ (Ref. No.: DC2012-220V, Biocare Medical, CA, USA) using the EnVision ${ }^{\mathrm{TM}}$ FLEX Target Retrieval Solution, High pH (Code No. DM828, Dako, Denmark) with the conditions of temperature $=110^{\circ} \mathrm{C}$ and time $=30 \mathrm{~min}$, followed by cooling at room temperature for $30 \mathrm{~min}$ and rinsing with running tap water for $3 \mathrm{~min}$. The slides were subsequently incubated with EnVisionTM FLEX Peroxidase-Blocking Reagent (Code No. DM821, Dako, Denmark) for 5 min, followed by washing steps. 
Slides were then incubated with primary antibody for $30 \mathrm{~min}$ at room temperature, followed by incubation with EnVisionTM FLEX/HRP (Code No. DM822, Dako, Denmark) for 30 min. Sections were then incubated with $1 \times$ DAB-containing substrate working solution for $5 \mathrm{~min}$. The slides were then counterstained with haematoxylin 2 (REF 7231, ThermoScientific, USA) for $5 \mathrm{~s}$. Then, the dehydration step was carried out with increasing alcohol solutions $(80 \%, 90 \%, 100 \%$ and $100 \%)$ and 2-times xylene. Finally, the slides were mounted using CoverSealTM-X xylene-based mounting medium (Cat. No.: FX2176, Cancer Diagnostics, USA).

\subsection{Evaluation of Antibodies Staining}

The analysis of immunohistochemical staining was performed by two independent observers (1 consultant pathologist (GCT) and 1 trainee pathologist (MXC)) blinded from the original histologic diagnosis. When there were discordant results, the slides were reviewed together, and a consensus was agreed upon.

PD-L1 expression was evaluated in tumour cells and immune cells. Immune cells are inflammatory cells such as lymphocytes, plasma cells and neutrophils, that participate in the defence mechanism in the body. All PD-L1 stained slides were scored for percentage of positive cells (score 0 -negative, $<1 \%-1,1$ to $10 \%-2,10$ to $30 \%-3,30$ to $60 \%-4$ and 60 to $100 \%-5$ ) and intensity of staining (score 0 -negative, weak -1 , moderate -2 and strong - 3 ), as previously described by Allred et al. [21] The intensity score represented the estimated average staining intensity of positive cell. The percentage and intensity scores were eventually added up to produce a final score that ranges from $2-8$. A score of $\geq 2$ is regarded as positive.

\subsection{Statistical Analysis}

Statistical analysis was performed using Statistical Package for Social Science (SPSS for MAC version 21.0, SPSS Inc., Chicago, IL, USA). All demographic data were expressed as mean with standard deviations. Categorical data were expressed as numbers of subjects and percentages. Chi-square test were used to compare PD-L1 expression between non-neoplastic endometrium and endometrium cancer, and to study the associations between PD-L1 expression and clinicopathological data. A value of $p<0.05$ is considered as statistically significant.

\section{Results}

\subsection{Demographic Data}

There was a total of 59 cases of endometrial carcinoma which were comprised of 51 endometrioid carcinomas, 3 serous carcinomas, 2 clear cell carcinomas, 2 mixed carcinomas and 1 mucinous carcinoma. The mean age of the patients was $53.5 \pm 12.0$ years. Thirty-two cases of non-neoplastic endometrium obtained from hysterectomy for leiomyoma were also included. The mean age of the non-neoplastic endometrium group was $48.9 \pm 8.8$ years old (Table 1 ).

Table 1. Demographic data with programmed death ligand 1 (PD-L1) expression profile in endometrial carcinoma.

\begin{tabular}{|c|c|c|c|c|c|c|}
\hline Parameters & & $n(\%)$ & $\begin{array}{c}\text { PD-L1 } \\
\text { Tumour Cells }\end{array}$ & $p$ Value & $\begin{array}{l}\text { PD-L1 Immune } \\
\text { Cells }\end{array}$ & $p$ Value \\
\hline \multirow{3}{*}{ Age } & Mean \pm SD (years) & $53.5 \pm 12.0$ & & \multirow{3}{*}{$0.047^{*}$} & & \multirow{3}{*}{0.432} \\
\hline & $<60$ & $36(61)$ & $7(19.4)$ & & $24(66.7)$ & \\
\hline & $\geq 60$ & $23(39)$ & $10(43.5)$ & & $13(56.5)$ & \\
\hline \multirow{3}{*}{ Race } & Malay & $32(54.2)$ & $10(31.3)$ & \multirow{3}{*}{0.575} & $19(59.4)$ & \multirow{3}{*}{0.847} \\
\hline & Chinese & $15(25.4)$ & $5(33.3)$ & & $10(66.7)$ & \\
\hline & Indian & $12(20.3)$ & $2(16.7)$ & & $8(66.7)$ & \\
\hline
\end{tabular}


Table 1. Cont.

\begin{tabular}{|c|c|c|c|c|c|c|}
\hline Parameters & & $n(\%)$ & $\begin{array}{c}\text { PD-L1 } \\
\text { Tumour Cells }\end{array}$ & $p$ Value & $\begin{array}{l}\text { PD-L1 Immune } \\
\text { Cells }\end{array}$ & $p$ Value \\
\hline \multirow{7}{*}{$\begin{array}{c}\text { Types of } \\
\text { endometrial } \\
\text { carcinoma }\end{array}$} & Endometrioid & $51(86.4)$ & & & & \\
\hline & Serous & $3(5.1)$ & & & & \\
\hline & Clear cell & $2(3.4)$ & & & & \\
\hline & Mixed & $2(3.4)$ & & & & \\
\hline & Mucinous & $1(1.7)$ & & & & \\
\hline & Type 1 & $52(88.1)$ & $14(26.9)$ & \multirow{2}{*}{0.40} & $33(63.5)$ & \multirow{2}{*}{1.0} \\
\hline & Type 2 & 7 (11.9) & $3(42.9)$ & & $4(57.1)$ & \\
\hline \multirow{3}{*}{ Grade } & 1 & $34(57.6)$ & $5(14.7)$ & \multirow{3}{*}{$0.01 *$} & $18(52.9)$ & \multirow{3}{*}{0.038 * } \\
\hline & 2 & $9(15.3)$ & $4(44.4)$ & & $8(88.9)$ & \\
\hline & 3 & $16(27.1)$ & $8(50)$ & & $11(68.8)$ & \\
\hline \multirow{4}{*}{ Stage } & 1 & $41(69.5)$ & $10(24.4)$ & \multirow{4}{*}{0.57} & $25(61.0)$ & \multirow{4}{*}{0.512} \\
\hline & 2 & 7 (11.9) & $2(28.6)$ & & $4(57.1)$ & \\
\hline & 3 & $6(10.2)$ & $3(50)$ & & $6(100)$ & \\
\hline & 4 & $5(8.5)$ & $2(40)$ & & $2(40)$ & \\
\hline \multirow{2}{*}{ Survival } & Alive & 44 & $7(15.9)$ & \multirow[t]{2}{*}{$0.001 *$} & $27(61.4)$ & \multirow[t]{2}{*}{0.767} \\
\hline & DOD & 15 & $10(66.7)$ & & $10(66.7)$ & \\
\hline \multirow{2}{*}{ PD-L1 positive } & Immune cells & $37(62.7)$ & & & & \\
\hline & Tumour cells & 17 (37.3) & & & & \\
\hline
\end{tabular}

\subsection{PD-L1 Expression Analysis}

\subsubsection{Endometrial Carcinoma versus Non-Neoplastic Endometrium}

Immunohistochemical staining for PD-L1 was performed on 59 endometrial carcinomas and 32 non-neoplastic endometrial tissues. We found that all non-neoplastic endometrial samples were negative for PD-L1 (Figure 1). In contrast, PD-L1 was expressed in $62.7 \%$ of the immune cells $(p<0.001)$ and $28.8 \%$ of the tumour cells $(p=0.001)$ (Figure 2, Table 2 ).

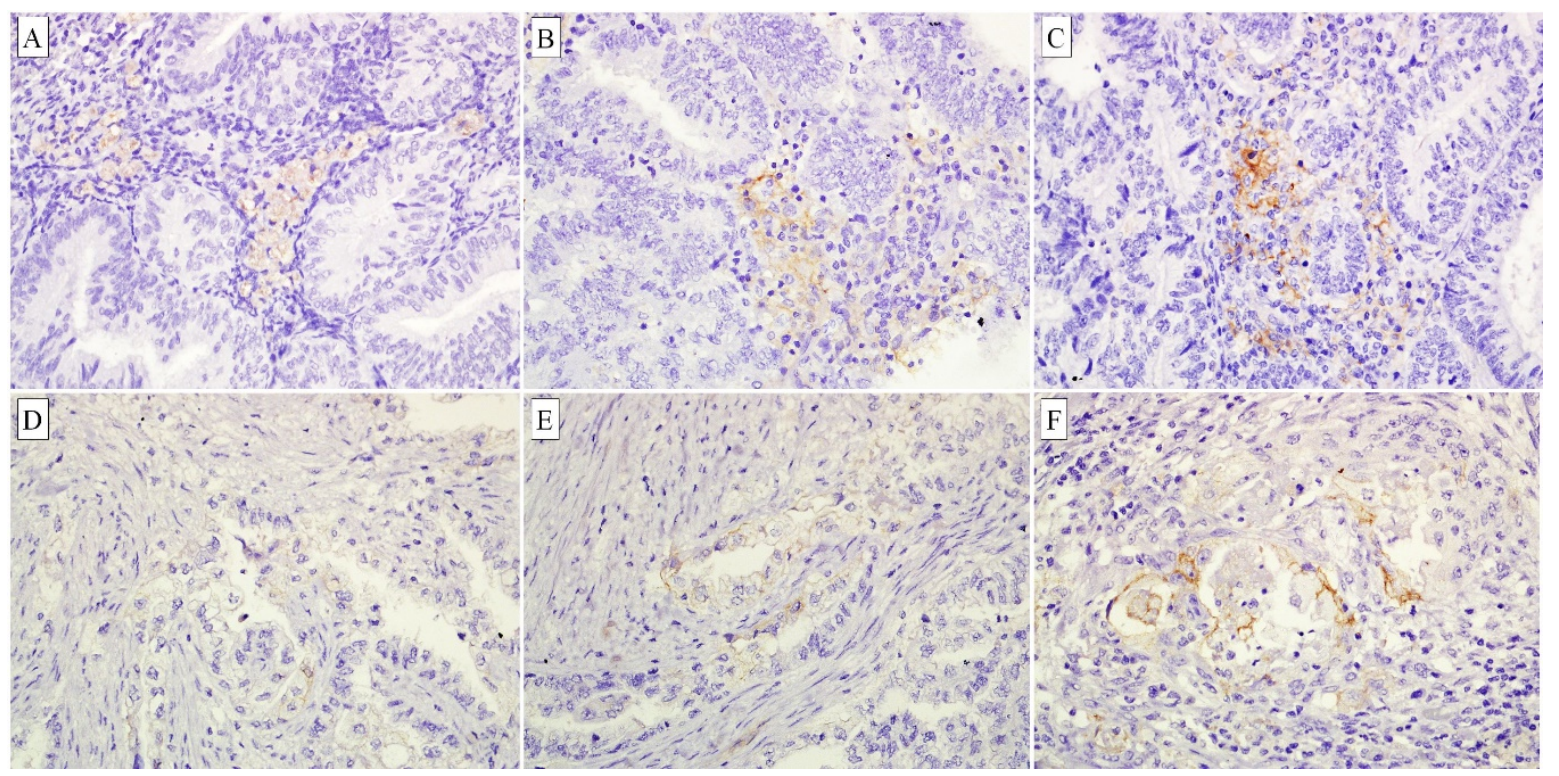

Figure 2. PD-L1 immunohistochemistry showed membranous staining in immune cells and tumour cells. (A-C) Weak, moderate and strong PD-L1 staining in immune cells (400×); (D-F) Weak, moderate and strong PD-L1 staining in tumour cells $(400 \times)$. 
Table 2. Expression of PD-L1 in immune cells and tumour cells.

\begin{tabular}{|c|c|c|c|c|}
\hline Types & $\begin{array}{l}\text { Total Number of } \\
\text { Cases }(n)\end{array}$ & $\begin{array}{l}\text { PD-L1 Positive in Immune } \\
\text { Cells } n(\%)\end{array}$ & $p$ Value & $\begin{array}{l}\text { PD-L1 Positive in Tumour } \\
\text { Cells } n(\%)\end{array}$ \\
\hline $\begin{array}{c}\text { Endometrial } \\
\text { carcinoma }\end{array}$ & 59 & 37 (62.7) & & $17(28.8)$ \\
\hline $\begin{array}{l}\text { Non-neoplastic } \\
\text { endometrium }\end{array}$ & 32 & $0(0)$ & $<0.001 *$ & NA \\
\hline
\end{tabular}

\subsubsection{Age $(\geq 60$ versus $<60$ Years $)$}

PD-L1 expression in tumour cells was more frequent in patients over 60 years of age compared to patients with endometrial carcinoma who are younger (43.5\% vs. 19.4\%, $p=0.047)$. On the other hand, regarding the expression in tumour-infiltrating immune cells, there was no statistically significant difference in PD-L1 expression between these age group $(p=0.432)$ (Table 1$)$.

\subsubsection{Ethnic Groups}

There is no statistically significant difference in PD-L1 expression between different ethnic groups in both the tumour cells $(p=0.432)$ and tumour-infiltrating immune cells $(p=0.847)$ (Table 1$)$.

\subsubsection{Type 1 versus Type 2 Endometrial Carcinoma}

The frequency of PD-L1 positivity in the tumour cells was higher in type 2 endometrial carcinoma compared to type 1 endometrial carcinoma. However, the difference was not statistically significant. $(42.9 \%$ vs. $26.9 \%, p=0.382)$ On the contrary, PD-L1 expression in tumour-infiltrating immune cells was slightly higher in type 1 endometrial carcinoma than type $2(63.5 \%$ vs. $57.1 \%, p=0.746)$ (Tables 1 and 3).

\subsubsection{Grade and Stage of Tumour}

In tumour cells, the frequency of PD-L1 expression was significantly higher in grade 2 and 3 endometrial carcinoma compared to grade 1 tumour (Table 1: $p=0.01$ ). There was no statistically significant difference between PD-L1 expression with different stages of endometrial carcinoma $(p=0.512)$.

\subsubsection{Survival (Alive versus Died of Disease)}

PD-L1 expression was significantly higher in patients who died of disease $(10 / 15,66.7 \%)$ than those who survived $(7 / 44,15.9 \%)(p=0.001)$ (Table 1$)$.

\subsubsection{Types of Therapy}

Hysterectomy with pelvic and aortic lymphadenectomy were performed in all endometrial carcinomas. In addition to hysterectomy, grade 3 endometrioid carcinoma as well as serous and clear cell carcinoma were treated with adjuvant therapy, either chemotherapy alone or concurrent chemotherapy with radiotherapy. The addition of adjuvant therapy also depends on the presence of risk of recurrence such as myometrial and lymphovascular invasions. 
Table 3. PD-L1 staining characteristics in tumour cells and immune cells of endometrial carcinoma.

\begin{tabular}{|c|c|c|c|c|c|c|c|}
\hline \multirow{2}{*}{$\begin{array}{c}\text { Types of } \\
\text { Tumour/Grading }\end{array}$} & \multirow{2}{*}{ No. } & \multicolumn{2}{|c|}{ Immune Cells } & \multicolumn{2}{|c|}{ Tumour Cells } & \multirow{2}{*}{ Stage } & \multirow{2}{*}{ Survival Status } \\
\hline & & Positive (\%) & Intensity & Positive (\%) & Intensity & & \\
\hline \multicolumn{8}{|c|}{ Type I } \\
\hline \multirow{33}{*}{ Endometroid G1 } & 1 & 0 & - & 10 & Moderate & 1 & DOD \\
\hline & 2 & 0 & - & 1 & Moderate & 1 & Alive \\
\hline & 3 & 0 & - & 0 & - & 2 & Alive \\
\hline & 4 & 0 & - & 0 & - & 1 & Alive \\
\hline & 5 & 0 & - & 0 & - & 1 & Alive \\
\hline & 6 & 35 & Moderate & 0 & - & 1 & Alive \\
\hline & 7 & 0 & - & 0 & - & 1 & Alive \\
\hline & 8 & 10 & Strong & $<1$ & Strong & 1 & Alive \\
\hline & 9 & 10 & Moderate & 0 & - & 1 & Alive \\
\hline & 10 & $<1$ & Weak & 1 & Strong & 3 & Alive \\
\hline & 11 & 0 & - & 0 & - & 1 & Alive \\
\hline & 12 & 0 & - & 0 & - & 1 & Alive \\
\hline & 13 & 0 & - & 0 & - & 1 & Alive \\
\hline & 14 & 0 & - & 0 & - & 1 & Alive \\
\hline & 15 & 1 & Strong & 0 & - & 1 & Alive \\
\hline & 16 & 5 & Strong & 0 & - & 1 & Alive \\
\hline & 17 & 0 & - & 0 & - & 2 & Alive \\
\hline & 18 & $<1$ & Weak & 0 & - & 1 & Alive \\
\hline & 19 & 10 & Strong & 0 & - & 1 & Alive \\
\hline & 20 & 5 & Weak & 0 & - & 1 & Alive \\
\hline & 21 & 10 & Strong & 0 & - & 1 & Alive \\
\hline & 22 & 1 & Strong & 1 & Strong & 1 & Alive \\
\hline & 23 & $<1$ & Strong & 0 & - & 1 & Alive \\
\hline & 24 & 0 & - & 0 & - & 1 & Alive \\
\hline & 25 & 2 & Strong & 0 & - & 1 & Alive \\
\hline & 26 & 40 & Strong & 0 & - & 2 & Alive \\
\hline & 27 & 0 & - & 0 & - & 1 & Alive \\
\hline & 28 & 0 & - & 0 & - & 1 & Alive \\
\hline & 29 & 0 & - & 0 & - & 1 & Alive \\
\hline & 30 & $<1$ & Moderate & 0 & - & 2 & Alive \\
\hline & 31 & 2 & Strong & 0 & - & 3 & Alive \\
\hline & 32 & 15 & Strong & 0 & - & 1 & Alive \\
\hline & 33 & 0 & - & 0 & - & 1 & Alive \\
\hline \multirow{9}{*}{ G2 } & 1 & 30 & Strong & 10 & Strong & 4 & DOD \\
\hline & 2 & 1 & Moderate & 10 & Moderate & 2 & Alive \\
\hline & 3 & 10 & Strong & 10 & Strong & 1 & DOD \\
\hline & 4 & 1 & Moderate & 10 & Moderate & 1 & DOD \\
\hline & 5 & $<1$ & Weak & 0 & - & 2 & Alive \\
\hline & 6 & 0 & - & 0 & - & 4 & DOD \\
\hline & 7 & 35 & Moderate & 0 & - & 1 & Alive \\
\hline & 8 & $<1$ & Moderate & 0 & - & 1 & Alive \\
\hline & 9 & 5 & Weak & 0 & - & 2 & DOD \\
\hline \multirow{9}{*}{ G3 } & 1 & 15 & Moderate & 10 & Strong & 1 & DOD \\
\hline & 2 & 0 & - & $<1$ & Weak & 1 & Alive \\
\hline & 3 & 5 & Strong & 30 & Strong & 1 & DOD \\
\hline & 4 & $<1$ & Weak & 0 & - & 3 & Alive \\
\hline & 5 & $<1$ & Weak & 0 & - & 1 & Alive \\
\hline & 6 & 0 & - & $<1$ & Weak & 1 & Alive \\
\hline & 7 & 1 & Weak & 0 & - & 1 & Alive \\
\hline & 8 & 10 & Strong & 1 & Weak & 4 & DOD \\
\hline & 9 & 5 & Strong & 0 & - & 1 & Alive \\
\hline Mucinous & 1 & 0 & - & 0 & - & 1 & Alive \\
\hline \multicolumn{8}{|c|}{ Type II } \\
\hline \multirow{3}{*}{ Serous } & 1 & $<1$ & Weak & $<1$ & Strong & 3 & DOD \\
\hline & 2 & 0 & - & 0 & - & 4 & DOD \\
\hline & 3 & 0 & - & 0 & - & 4 & DOD \\
\hline \multirow{2}{*}{ Clear cell } & 1 & 1 & Weak & 0 & - & 1 & Alive \\
\hline & 2 & 15 & Strong & $<1$ & Strong & 3 & DOD \\
\hline \multirow{2}{*}{ Mixed } & 1 & 1 & Moderate & 0 & - & 1 & DOD \\
\hline & 2 & 0 & - & 2 & Moderate & 2 & DOD \\
\hline
\end{tabular}

No.: Number, G1: Grade 1, G2: Grade 2, G3: Grade 3, DOD: died of disease. 


\section{Discussion}

PD-L1 is expressed in different types of tumour cells and in the tumour microenvironment, including infiltrating immune cells. The tumour cells can upregulate PD-L1 expression which leads to inhibition of T-cells function and impedes antitumour immunity, subsequently avoiding immune destruction by the immune system. Previous studies showed that PD-L1 expression by tumour cells correlated with poor prognosis, while PD-L1 expression by tumour-infiltrating immune cells was associated with better overall survival [22-26]. In this study, we also found that PD-L1 expression in tumour cells is associated with poorer survival.

This study showed that PD-L1 was positive in $62.7 \%$ of tumour-infiltrating immune cells and $37.3 \%$ of the tumour cells in endometrial carcinoma (Table 4). This finding is comparable with other studies, such as that of Mo et al., in which PD-L1 was positive in $60 \%$ of immune cells and $17.3 \%$ of tumour cells [8]. However, they found that $14.3 \%$ of normal endometrium also expressed PD-L1 [8]. On the contrary, Vanderstraeten et al. reported that approximately $80 \%$ of both tumour cells of endometrial carcinoma and normal endometrium expressed PD-L1 [19].

Table 4. Comparison of PD-L1 expression in present study with previous studies.

\begin{tabular}{cccc}
\hline \multirow{2}{*}{ References } & \multicolumn{3}{c}{ PD-L1 Expression } \\
\cline { 2 - 4 } & Tumour-infiltrating Immune Cells & Tumour Cells & Normal Endometrium \\
\hline Present study (2019) & $62.7 \%$ & $28.8 \%$ & $0 \%$ \\
Vanderstraeten et al., 2014 [19] & NA & $70-80 \%$ & $81 \%$ \\
Mo et al., 2016 [8] & $60 \%$ & $17.3 \%$ & $14.3 \%$ \\
Sungu et al., 2019 [27] & $36.2 \%$ & $36.2 \%$ & NA \\
\hline
\end{tabular}

NA: not available.

All of our non-neoplastic endometrium was negative for PD-L1. This finding differs from the two previous studies by Mo et al. [8] and Vanderstraeten et al. [19], which reported that PD-L1 were positive in approximately $14 \%$ and $81 \%$, respectively. Although the immunohistochemistry (IHC) method is predominantly used in the detection of PD-L1 expression, the result is affected by preanalytical and analytical variabilities. The significant difference between the current study and the study by Mo et al., 2016 could be due to the different antibody and IHC protocol used. For example, a rabbit polyclonal antibody with a dilution of 1:400 was used by Mo et al., 2016 while in our study, a rabbit monoclonal to PD-L1 was used at a dilution of 1:500. Therefore, it is justified that Mo et al., 2016 could find more PD-L1 positive cases than in the present study, since the polyclonal antibody has a higher sensitivity when detecting low-quantity proteins, while the monoclonal antibody is more susceptible to changes in antigen conformation due to processing or fixation [28].

In the current study, we have observed that the immunoreactivity for PD-L1 was focal in most of the positive cases. According to Wang et al., 2016, there are multiple factors that affect the immunohistochemical expression of PD-L1 in cancer cells. This includes different types of antibody being used, the difference in cut-off value of PD-L1 staining positivity, and the difference in timing and location of tissue sampling [29]. Therefore, even from the same tumour, the PD-L1 expression may differ, and this is due to focal nature of PD-L1 expression in the tumour [29].

Mo and colleagues found that type 2 endometrial carcinoma had a 100\% positive rate of PD-L1 [8]. However, our study showed no significant difference in PD-L1 expression between type 1 and type 2 endometrial carcinoma, in both tumour cells and immune cells. In the grading of endometrial carcinoma, PD-L1 expression in both tumour cells and immune cells were significantly higher in grade 2 and 3 compared to grade 1 tumours. This finding is similar to Mo et al. [8]. Interestingly, in the group of patients with endometrial carcinoma who died of disease, 10 of the 14 patients $(71.4 \%)$ had positive PD-L1 in tumour cells. This is in contrast to the fact that only 7 of the 55 patients $(12.7 \%)$ had positive PD-L1 among patients who are alive. This suggests that PD-L1 expression in tumour cells may be used as a predictor of patient survival or as a prognostic marker. It should be mentioned that PD-L1 expression in immune cells does not seem to have a clear value as a prognostic factor and is positive 
in only about two out of three cases of endometrial carcinoma. Apart from endometrial carcinoma, PD-L1 overexpression has been shown in previous studies to be a poor prognostic factor in several other tumours. In a meta-analysis by Wang et al., PD-L1 overexpression was associated with poorer overall survivals in breast cancer, gastric cancer, urothelial cancer and renal cell carcinoma, while in melanoma, hepatocellular carcinoma, and renal cell carcinoma, PD-L1 overexpression was significantly associated with poorer progression-free survivals [30]. However, there were some discrepancies in the prognostic value of PD-L1 for endometrial carcinoma in previous studies. Zhang et al., 2020 [31] reported that high PD-L1 in TCs was associated with better overall survival, while high PD-L1 in TICs was associated with worse overall survival. In contrast, Engerud et al., 2020 [32] reported that PD-L1 expression in tumour cells was significantly associated with higher grade tumours, with no association with overall survival. The discrepancy might be due to the difference in antibody used, the duration of tissue sample storage, and the method used to assess the antibody expression.

A previous study by Yamazawa et al. showed that young women with endometrial cancer had a better outcome due to a significantly higher percentage of early stage cancer and less myometrial invasion in this age group [33]. This study showed that PD-L1 expression in the tumour cells was more common in patients $\geq 60$ years $(43.5 \%)$ compared to younger patients $<60$ years $(19.4 \%)$.

Kanopiene et al., 2015 reported that $17 \%$ of endometrial carcinomas have microsatellite instability (MSI) [34]. Subsequently, another study found no difference between PD-L1 expression in MSI and microsatellite stable (MSS) tumours [32].

PD-1 and PD-L1 expressions within the tumour microenvironment are important in the regulation between activation and tolerance of T-lymphocytes during prolonged antigenic exposure [35]. In a study using animal model, the inhibition of PD-1/PD-L1 resulted in an autoimmune reaction [36]. The use of anti-PD-1/PD-L1 in immune-oncology in tumours was recognised as the "breakthrough of the year" in 2013 [37]. Antibodies targeting PD-1/PD-L1 interactions have been approved by the Food and Drug Administration (FDA) in seven types of malignancies, namely, melanoma, nonsmall cell lung carcinoma, renal cell carcinoma, urothelial carcinoma, colorectal carcinoma, head and neck squamous cell carcinoma and Hodgkin lymphoma [35]. To date, nivolumab, pembrolizumab and cemilimab are the FDA approved anti-PD-1 agents, while atezolizumab, durvalumab and avelumab are examples of PD-L1 inhibitors [38].

\section{Conclusions}

In conclusion, we demonstrated that PD-L1 was expressed in endometrial cancer, but not in normal endometrium. PD-L1 has prognostic value in endometrial carcinoma as it is more commonly expressed in higher grade tumours and is significantly associated with a poorer survival. This study also suggests that immunomodulation such as PD-L1 inhibitors may be useful in the treatment of advanced endometrial cancer.

Author Contributions: Conceptualization, G.C.T.; methodology, M.C., M.M., N.A. and G.C.T.; formal analysis, M.C. and G.C.T.; data curation, M.C., M.M. and N.A.; writing-original draft preparation, M.C.; writing-review and editing, M.C., Y.P.W. and G.C.T.; supervision, Y.P.W., N.K. and G.C.T.; project administration, G.C.T.; funding acquisition, G.C.T. All authors have read and agreed to the published version of the manuscript.

Funding: We would like to express our sincere thanks to the Faculty of Medicine, Universiti Kebangsaan Malaysia (FF-2018-052) for providing the research fund for this study.

Acknowledgments: This study was presented at Malaysian-Indonesian-Brunei Medical Science Conference on 19-20 September 2019 and obtained third best oral presentation.

Conflicts of Interest: The authors declare no conflict of interest.

\section{References}

1. National Cancer Institute: SEER Stat Fact Sheets: Endometrial Cancer. Available online: https://seer.cancer. gov/statfacts/html/corp.html (accessed on 12 November 2019). 
2. The Malaysian National Cancer Registry Report (MNCR) 2007-2011. 2016. Available online: https: //kpkesihatan.com/2016/12/07/the-malaysian-national-cancer-registry-report-mncr-2007-2011/ (accessed on 15 February 2020).

3. Longoria, T.C.; Eskander, R.N. Immunotherapy in endometrial cancer-an evolving therapeutic paradigm. Gynecologic oncology research and practice. Gynecol. Oncol. Res. Pract. 2015, 2, 11. [CrossRef] [PubMed]

4. Lortet-Tieulent, J.; Ferlay, J.; Bray, F.; Jemal, A. International Patterns and Trends in Endometrial Cancer Incidence, 1978-2013. J. Natl. Cancer Inst. 2018, 110, 354-361. [CrossRef] [PubMed]

5. Bokhman, J.V. Two pathogenetic types of endometrial carcinoma. Gynecol. Oncol. 1983, 15, 10-17. [CrossRef]

6. Setiawan, V.W.; Yang, H.P.; Pike, M.C.; McCann, S.E.; Yu, H.; Xiang, Y.B.; Wolk, A.; Wentzensen, N.; Weiss, N.S.; Webb, P.M.; et al. Type I and II endometrial cancers: Have they different risk factors? J. Clin. Oncol. 2013, 31, 2607-2618. [CrossRef] [PubMed]

7. Lacey, J.V., Jr.; Sherman, M.E.; Rush, B.B.; Ronnett, B.M.; Ioffe, O.B.; Duggan, M.A.; Glass, A.G.; Richesson, D.A.; Chatterjee, N.; Langholz, B. Absolute risk of endometrial carcinoma during 20-year follow-up among women with endometrial hyperplasia. J. Clin. Oncol. 2010, 28, 788-792. [CrossRef]

8. Mo, Z.; Liu, J.; Zhang, Q.; Chen, Z.; Mei, J.; Liu, L.; Yang, S.; Li, H.; Zhou, L.; You, Z. Expression of PD-1, PD-L1 and PD-L2 is associated with differentiation status and histological type of endometrial cancer. Oncol. Lett. 2016, 12, 944-950. [CrossRef]

9. Fleming, G.F.; Brunetto, V.L.; Cella, D.; Look, K.Y.; Reid, G.C.; Munkarah, A.R.; Kline, R.; Burger, R.A.; Goodman, A.; Burks, R.T. Phase III trial of doxorubicin plus cisplatin with or without paclitaxel plus filgrastim in advanced endometrial carcinoma: A Gynecologic Oncology Group Study. J. Clin. Oncol. 2004, 22, 2159-2166. [CrossRef]

10. Pectasides, D.; Pectasides, E.; Economopoulos, T. Systemic therapy in metastatic or recurrent endometrial cancer. Cancer Treat. Rev. 2007, 33, 177-190. [CrossRef]

11. Pardoll, D.M. The blockade of immune checkpoints in cancer immunotherapy. Nat. Rev. Cancer 2012, 12, 252-264. [CrossRef]

12. Dong, H.; Zhu, G.; Tamada, K.; Chen, L. B7-H1, a third member of the B7 family, co-stimulates T-cell proliferation and interleukin-10 secretion. Nat. Med. 1999, 5, 1365-1369. [CrossRef]

13. Philips, G.K.; Atkins, M. Therapeutic uses of anti-PD-1 and anti-PD-L1 antibodies. Int. Immunol. 2014, 27, 39-46. [CrossRef] [PubMed]

14. Massi, D.; Brusa, D.; Merelli, B.; Ciano, M.; Audrito, V.; Serra, S.; Buonincontri, R.; Baroni, G.; Nassini, R.; Minocci, D.; et al. PD-L1 marks a subset of melanomas with a shorter overall survival and distinct genetic and morphological characteristics. Ann. Oncol. 2014, 25, 2433-2442. [CrossRef]

15. Iacovelli, R.; Nolè, F.; Verri, E.; Renne, G.; Paglino, C.; Santoni, M.; Rocca, M.C.; Giglione, P.; Aurilio, G.; Cullurà, D.; et al. Prognostic role of PD-L1 expression in renal cell carcinoma. A systematic review and meta-analysis. Target. Oncol. 2016, 11, 143-148. [CrossRef] [PubMed]

16. McLaughlin, J.; Han, G.; Schalper, K.A.; Carvajal-Hausdorf, D.; Pelekanou, V.; Rehman, J.; Velcheti, V.; Herbst, R.; LoRusso, P.; Rimm, D.L. Quantitative assessment of the heterogeneity of PD-L1 expression in non-small-cell lung cancer. JAMA Oncol. 2016, 2, 46-54. [CrossRef] [PubMed]

17. Herzog, T.; Arguello, D.; Reddy, S.; Gatalica, Z. PD-1 and PD-L1 expression in 1599 gynecological malignancies: Implications for immunotherapy. Gynecol Oncol. 2015, 137, 204-205. [CrossRef]

18. Pinto, A.; Mackrides, N.; Nadji, M. PD-L1 Expression in carcinosarcomas of the gynecologic Tract: A potentially actionable biomarker. Appl. Immunohistochem. Mol. Morphol. 2018, 26, 393-397. [CrossRef] [PubMed]

19. Vanderstraeten, A.; Luyten, C.; Verbist, G.; Tuyaerts, S.; Amant, F. Mapping the immunosuppressive environment in uterine tumors: Implications for immunotherapy. Cancer Immunol. Immun. 2014, 63, 545-557. [CrossRef] [PubMed]

20. Gandini, S.; Massi, D.; Mandalà, M. PD-L1 expression in cancer patients receiving anti PD-1/PD-L1 antibodies: A systematic review and meta-analysis. Crit. Rev. Oncol. Hemat. 2016, 100, 88-98. [CrossRef]

21. Allred, D.C.; Clark, G.M.; Elledge, R.; Fuqua, S.A.; Brown, R.W.; Chamness, G.C.; Osborne, C.K.; McGuire, W.L. Association of p53 protein expression with tumor cell proliferation rate and clinical outcome in node-negative breast cancer. J. Natl. Cancer Inst. 1993, 85, 200-206. [CrossRef] 
22. Liu, C.Q.; Xu, J.; Zhou, Z.G.; Jin, L.L.; Yu, X.J.; Xiao, G.; Lin, J.; Zhuang, S.M.; Zhang, Y.J.; Zheng, L. Expression patterns of programmed death ligand 1 correlate with different microenvironments and patient prognosis in hepatocellular carcinoma. Br J Cancer. 2018, 119, 80-88. [CrossRef]

23. Birtalan, E.; Danos, K.; Gurbi, B.; Brauswetter, D.; Halasz, J.; Kalocsane Piurko, V.; Acs, B.; Antal, B.; Mihalyi, R.; Pato, A.; et al. Expression of PD-L1 on immune cells shows better prognosis in laryngeal, oropharygeal, and hypopharyngeal cancer. Appl. Immunohistochem. Mol. Morphol. 2018, 26, e79-e85. [CrossRef] [PubMed]

24. Drakes, M.L.; Mehrotra, S.; Aldulescu, M.; Potkul, R.K.; Liu, Y.; Grisoli, A.; Joyce, C.; O’Brien, T.E.; Stack, M.S.; Stiff, P.J. Stratification of ovarian tumor pathology by expression of programmed cell death-1 (PD-1) and PD-ligand- 1 (PD-L1) in ovarian cancer. J. Ovarian Res. 2018, 11, 43. [CrossRef]

25. Pulko, V.; Harris, K.J.; Liu, X.; Gibbons, R.M.; Harrington, S.M.; Krco, C.J.; Kwon, E.D.; Dong, H. B7-h1 expressed by activated CD8 T-cells is essential for their survival. J Immunol. 2011, 187, 5606-5614. [CrossRef]

26. Marinelli, O.; Annibali, D.; Aguzzi, C.; Tuyaerts, S.; Amant, F.; Morelli, M.B.; Santoni, G.; Amantini, C.; Maggi, F.; Nabissi, M. The Controversial Role of PD-1 and Its Ligands in Gynecological Malignancies. Front. Oncol. 2019, 9, 1073. [CrossRef] [PubMed]

27. Sungu, N.; Yildirim, M.; Desdicioglu, R.; Başaran Aydoğdu, Ö.; Kiliçarslan, A.; Tatli Doğan, H.; Kiliç Yazgan, A.; Akyol, M.; Erdoğan, F. Expression of immunomodulatory molecules PD-1, PD-L1, and PD-L2, and their relationship with clinicopathologic characteristics in endometrial cancer. Int. J. Gynecol. Pathol. 2019, 38, 404-413. [CrossRef] [PubMed]

28. Panawala, L. Difference between Monoclonal and Polyclonal Antibodies. 2017. Available online: https://www.researchgate.net/publication/320707210_Difference_Between_Monoclonal_and_Polyclonal_ Antibodies (accessed on 15 February 2020).

29. Wang, X.; Teng, F.; Kong, L.; Yu, J. PD-L1 expression in human cancers and its association with clinical outcomes. Onco Targets Ther. 2016, 9, 5023.

30. Wang, Q.; Liu, F.; Liu, L. Prognostic significance of PD-L1 in solid tumor: An updated meta-analysis. Medicine 2017, 96, e6369. [CrossRef]

31. Zhang, S.; Minaguchi, T.; Xu, C.; Qi, N.; Itagaki, H.; Shikama, A.; Tasaka, N.; Akiyama, A.; Sakurai, M.; Ochi, H.; et al. PD-L1 and CD4 are independent prognostic factors for overall survival in endometrial carcinomas. BMC Cancer 2020, 20, 127. [CrossRef]

32. Engerud, H.; Berg, H.F.; Myrvold, M.; Halle, M.K.; Bjorge, L.; Haldorsen, I.S.; Hoivik, E.A.; Trovik, J.; Krakstad, C. High degree of heterogeneity of PD-L1 and PD-1 from primary to metastatic endometrial cancer. Gynecol. Oncol. 2020, 157, 260-267. [CrossRef]

33. Yamazawa, K.; Seki, K.; Matsui, H.; Kihara, M.; Sekiya, S. Prognostic factors in young women with endometrial carcinoma: A report of 20 cases and review of literature. Int. J. Gynecol. Cancer. 2000, 10, 212-222. [CrossRef]

34. Kanopiene, D.; Vidugiriene, J.; Valuckas, K.P.; Smailyte, G.; Uleckiene, S.; Bacher, J. Endometrial cancer and microsatellite instability status. Open Med. (Wars) 2014, 10, 70-76. [CrossRef] [PubMed]

35. Kythreotou, A.; Siddique, A.; Mauri, F.A.; Bower, M.; Pinato, D.J. PD-L1. J. Clin. Pathol. 2018, 71, $189-194$. [CrossRef] [PubMed]

36. Nishimura, H.; Nose, M.; Hiai, H.; Minato, N.; Honjo, T. Development of lupus-like autoimmune diseases by disruption of the PD-1 gene encoding an ITIM motif-carrying immunoreceptor. Immunity 1999, 11, 141-151. [CrossRef]

37. Couzin-Frankel, J. Breakthrough of the year 2013. Cancer Immunother. Sci. 2013, 342, 1432-1433.

38. Cancer Research Institute. Available online: https://www.cancerresearch.org/scientists/immuno-oncologylandscape/fda-approval-timeline-of-active-immunotherapies (accessed on 12 January 2020).

(C) 2020 by the authors. Licensee MDPI, Basel, Switzerland. This article is an open access article distributed under the terms and conditions of the Creative Commons Attribution (CC BY) license (http://creativecommons.org/licenses/by/4.0/). 